\title{
Representasi Figur Burung Garuda yang Digunakan sebagai Lambang Negara
}

\author{
Yurica Oentoro \\ Program Studi Desain Komunikasi Visual, Fakultas Seni dan Desain, \\ Universitas Kristen Petra \\ Email: aura_lyrone@hotmail.com
}

\begin{abstract}
Abstrak
Terdapat tiga lambang negara yang memiliki tingkat kemiripan yang sangat tinggi, yaitu Indonesia, Romania dan Uni Emirat Arab. Ketiga negara ini menggunakan figur burung pada lambang negaranya. Persepsi yang dimiliki oleh ketiga negara tentang simbolisasi makna dari burung adalah sama. Namun penggambaran dari bentuk dan jenis burung berbeda tiap negara. Hal itu disebabkan karena spesies burung yang gunakan oleh tiap negara berbeda antara yang satu dengan lainnya. Perbedaan persepsi juga meliputi tentang apa yang ditampilkan dalam lambang negara. Penelitian ini menggunakan Visual Methodologies dari aspek site of image itself dengan menggunakan compositional interpretation dan Semiotika Peirce untuk menganalisa lambang negara dari ketiga negara tersebut. Tujuan dari penelitian ini adalah untuk mengetahui makna dibalik ketiga lambang negara yang memiliki tingkat kemiripan yang tinggi.
\end{abstract}

Kata kunci: Burung, Garuda, Lambang Negara, Indonesia, Romania, Uni Emirat Arab, Semiotika.

\begin{abstract}
There are three coat of arms which have high level of similarities, such as Indonesia, Romania, and United Arab Emirates. These three nations the use bird figure as their coat of arms. These three nation's perception for the meaning of the bird is same. However, the depiction of the bird's form is different for each nation. It's because each nation is using a different species of birds. The differences in perception also includes what is shown in the coat of arms. This research used Visual Methodologies from the site of image itself with compositional interpretation and Peirce's semiotics to analyze these three coat of arms. The purpose of this research is to know the meaning behind the three coat of arms which have high level of similarities.
\end{abstract}

Keywords: Bird, Garuda, Coat of Arms, Indonesia, Romania, United Arab Emirates, Semiotic.

\section{Pendahuluan}

Penggunaan burung garuda sebagai lambang Negara tidak hanya digunakan oleh Indonesia saja. Banyak negara-negara yang menggunakan burung garuda sebagai lambang negaranya, seperti Amerika Serikat, Mesir, Irak, Romania, Libya dan Uni Emirat Arab. Keenam negara ini tersebar di empat benua, yaitu Asia, Amerika, Eropa dan Afrika, yang mana membuktikan bahwa penggunaan burung garuda sebagai lambang negara telah dikenal di seluruh dunia. Penggunaan dari bentuk garuda sebagai lambang negara mengalamai modifikasi hingga dapat menyesuaikan dengan pencitraan yang diinginkan oleh suatu negara.

Dalam penelitian ini, lambang negara yang diteliti adalah Indonesia, Rumania dan Uni Emirat Arab. Ketiga negara ini dipilih karena adanya tingkat kemiripan yang paling tinggi antara lambang negara satu dengan satunya, seperti posisi kepala yang menengok ke kanan, perisai yang ada didada serta kaki yang mencengkeram. Penggunaan burung garuda sebagai lambang negara sangat menarik untuk diteliti. Dengan adanya ilmu yang mempelajari tentang tanda, yaitu semiotika, diharap dapat memberikan penjelasan tentang makna yang terkandung dalam lambang negara tersebut dan alasan penggunaan burung garuda sebagai bentuk dasar lambang negara. Permasalah yang diangkat adalah untuk mengetahui makna yang terkadung dalam sebuah lambang negara yang direpresentasikan secara mirip oleh ketiga Negara, yaitu Indonesia, Romania dan Uni Emirat Arab.

\section{Metode Penelitian}

Metode penelitian yang digunakan adalah metode kualitatif. Metode kualitatif adalah proses berpikir yang lebih menekankan pada makna, definisi dari suatu gejala yang terjadi di masyarakat. Proses penggumpulan data dilakukan dengan melakukan 
studi dokumentasi. Studi dokumentasi dilakukan dengan membaca dan menganalisa tulisan-tulisan yang terdapat dalam buku, jurnal, artikel, dan lain sebagainya. Di dalam penelitian ini data yang didapat berupa data deskriptif, yaitu data yang menjelaskan tentang suatu peristiwa atau gejala yang terjadi dalam masyarakat. Alur dari penelitian analisis data yang digunakan adalah visual metodologi. Dalam visual metodologi terdapat tiga pendekatan yaitu yaitu the site of the production, the image itself, dan the site of audience. Ketiga aspek tersebut tidak boleh dikaitkan antara satu dan yang lainnya, sehingga setiap aspek dapat berdiri secara sendiri-sendiri. Dalam penelitian yang dilakukan, cara yang paling efektif untuk memahami suatu karya visual adalah dengan mengerti tentang komponen-komponen yang menyusunnya, bukan tentang bagaimana karya itu dibuat ataupun keadaan sosialnya. Pada pendekatan image itself terdapat beberapa teknik dan analisa yang dapat digunakan sebagai pemecahan masalah, seperti psikoanalisis, semiotika, dan analisa isi. Pemilihan penggunaan teknik dan analisa semiotika berdasarkan pada permasalah yang dihadapi, dalam konteks ini adalah lambang negara. Lambang negara merupakan sebuah tanda yang dibuat berdasarkan pada pencitraan bangsa Sedangkan semiotika adalah ilmu yang mempelajari tentang tanda. Semiotika berasal dari bahasa yunani "semeion" yang memiliki arti "tanda". Semiotika yang biasanya didefinisikan sebagai pengkajian tanda-tanda (the study of sign), pada dasarnya merupakan sebuah studi atas kodekode, yaitu sistem apapun yang memungkinkan untuk memandang entitas-entitas tertentu sebagai tanda-tanda atau sebagai sesuatu yang bermakna (Budiman, 2011:1). Pada dasarnya semiotika mempelajari tentang bagaimana kemanusiaan memaknai hal-hal, memaknai tidak hanya memberikan informasi tetapi juga memberikan komunikasi. Semiotika adalah suatu disiplin yang menyelidiki semua bentuk komunikasi yang terjadi dengan sarana tanda dan berdasarkan pada sistem tanda. Semiotika adalah suatu ilmu atau metode analisis untuk mengkaji tanda secara sistematik menejelaskan esensi, ciri-ciri, dan bentuk suatu tanda, serta proses signifikasi yang menyertainya (Sobur, 2009:15-17). Semiotika tidak hanya mengkaji makna, terlepas dari pembedaan yang mungkin dilakukan oleh semiotisi tertentu atas arti dan makna. Semiotika tidak hanya mempelajari simbol, tetapi tanda yang memiliki

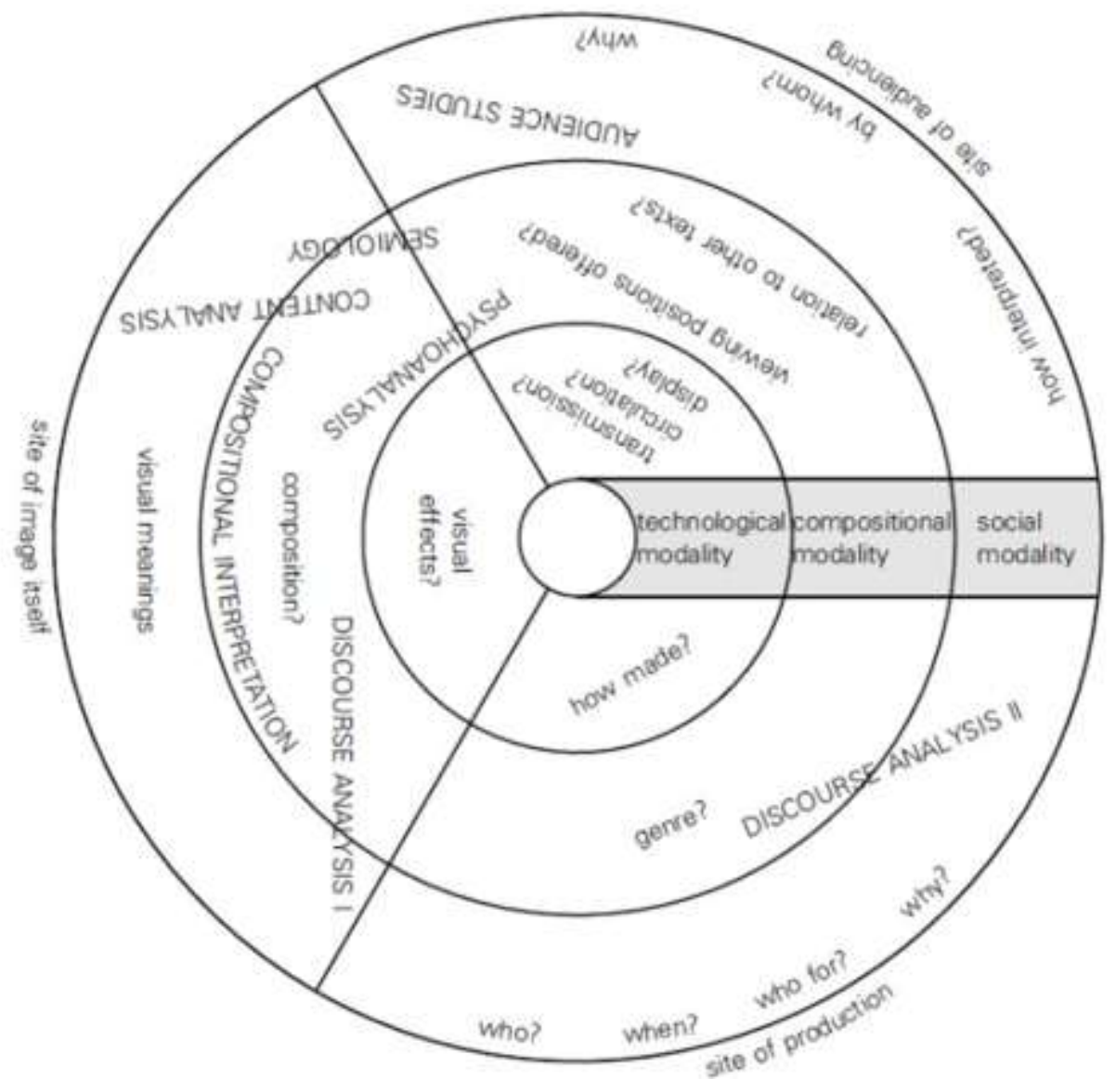

Sumber: Rose, 2001: 30

Gambar 1. Teknik analisa dalam visual metodologis 
cakupan yang lebih luas. Semiotika memang mengkaji tentang tanda tetapi yang lebih penting adalah relasi atau hubungan antara tanda dan interpretasinya (Budiman, 2011:vii-viii). Sehingga pendekatan yang digunakan dalam penelitian adalah pendekatan image itself dengan teknik dan analisis semiotika.

Pemilihan teori semiotika Peirce berdasarkan pada kebutuhan dan kegunaan teori jika ditemukan dengan objek penelitian. Semiotika menurut Peirce adalah sinonim dari kata logika. Dengan adanya tanda maka manusia dapat menggunakan pemikirannya untuk mengungkap makna dari hal yang mereka lihat atau terjadi di alam semesta. Peirce mengungkapkan bahwa dalam semiotika yang dianut mengandung 3 elemen, yaitu tanda itu sendiri, objek yang mengacu pada tanda itu, dan penafsiran yang menghubungkan tanda dengan objek itu. Keberadaan suatu tanda menyebabkan terjadinya hubungan sebab-akibat dengan tanda tersebut karena adanya ikatan konvensional dengan tanda-tanda tersebut.

Peirce membagi ilmu tandanya ke dalam 3 istilah, yaitu ikon, indeks dan simbol (Budiman, 2011; Sobur, 2009; Chandler, 2007; Hoopes. 1991). Ikon adalah tanda yang hubungan antara penanda dan pertandanya berdasarkan pada kemiripian (resemblance) yang dapat diketahui oleh pemakainya, peta atau lukisan misalnya. Ikon sebenarnya tidak hanya mencakup hal-hal realitas seperti lukisan atau potret saja, tetapi dapat mencakup hal yang lebih luas seperti persamaan dalam matematika, peta geografis, skema maupun grafik. Pengertian bahwa ikon berdasarkan pada kemiripan dapat menjelaskan bahwa segala sesuatu merupakan ikon, karena pada kenyataannya segala sesuatu dapat dikaitkan dengan sesuatu yang lain. Di jaman yang semakin berkembang seperti sekarang ini dapat lebih memperluas lagi penggunaan tanda sebagai ikonik. Hal ini dapat dilihat dari bahasa yang kini dilambangkan dengan gambar atau tanda. Tanda-tanda ikonis dapat dimanfaatkan untuk pengolah informasi secara cepat, seperti penggunaan diagram, rumus, skema dan lain sebagainya.

Indeks adalah tanda yang memiliki keterikatan fenomenal atau eksistensial diantara representamen dan objeknya. Di dalam indeks hubungan antara dan objeknya bersifat konkret, aktual, dan biasanya melalui cara yang sekuensial atau kausal. Indeks mengindikasikan sesuatu hal seperti contohnya jam yang mengindikasikan waktu.

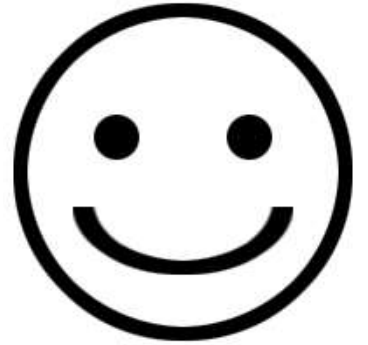

Sumber: Budiman, 2011:83

Gambar 2. Contoh ikon

Peirce menjelaskan bahwa relasi antara tanda dan objek tidak sepenuhnya bergantung pada pemikiran. Objek memiliki sebuah kenampakan dan hubungan antara indeks dan objeknya adalah nyata.

Berbeda dengan ikon, indeks memiliki hubungan yang nyata dan indeks merupakan sebuah potongan yang diambil dari objek. Ikon berdasarkan pada kemiripan sedangkan indeks berdasarkan pada hubungan atau relasi. Jejak telapak kaki di atas permukaan tanah, misalnya, menindikasikan seseorang yang melewati tanah tersebut. Kata rokok memiliki indeks asap. Hubungan indeksikal antara rokok dengan asap terjadi karena terdapatnya hubungan ciri yang bersifat tetap antara rokok dan asap.

Kata-kata yang memiliki hubungan indeksikal masing-masing memiliki cirri utama secara individual. Ciri tersebut antara yang satu dengan yang lain berbeda dan tidak dapat saling menggantikan. Ciri utama pada rokok misalnya, berbeda dengan asap. Sebuah foto menurut Peirce tidak hanya merupakan ikon tetapi juga merupakan indeks. Gambar yang diambil menggunakan kamera mempunyai bentuk yang mirip dengan gambar aslinya tetapi kemiripan ini dipaksakan dengan melakukan berbagai macam prosedur untuk menghasilkan gambar yang sama. Jadi, karena gambar yang dihasilkan merupakan indikasi dari pencahayaan maka semua hasil foto dan gambar merupakan indeks. Selain itu, indeks pun dapat terwujud atau teraktualitas di dalam kata petunjuk (demonstratives) seperti ini, itu, di sini, di situ; kata ganti persona (personal pronous) seperti aku, engkau; gerak gerik (gesture) seperti jari telunjuk yang menuding.

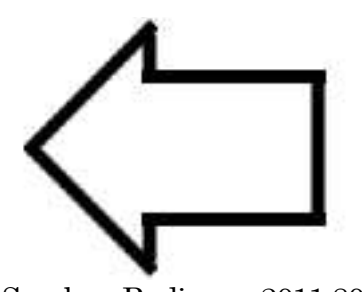

Sumber: Budiman, 2011:80

Gambar 3. Contoh indeks 
Simbol adalah tanda yang representamennya merujuk pada objek tertentu tanpa motivasi (unmotivated); simbol terbentuk melalui konvensikonvensi atau kaidah-kaidah, tanpa adanya kaitan langsung diantara representamen dan objeknya. Kebanyakan unsur leksikal di dalam kosa kata suatu bahasa adalah simbol. Misalkan kata pohon dalam bahasa Indonesia, yang disebut wit dalam bahasa jawa dan tree dalam bahasa inggris, adalah simbol karena relasi diantara kata tersebut sebagai representamen dan pohon asli yang menjadi objeknya tidak bermotivasi, semata-mata konvensional. Namun demikian tidak hanya bahasa yang sesungguhnya tersusun dari simbolsimbol. Gerak gerik mata, tangan, atau jari jemari merupakan simbol.
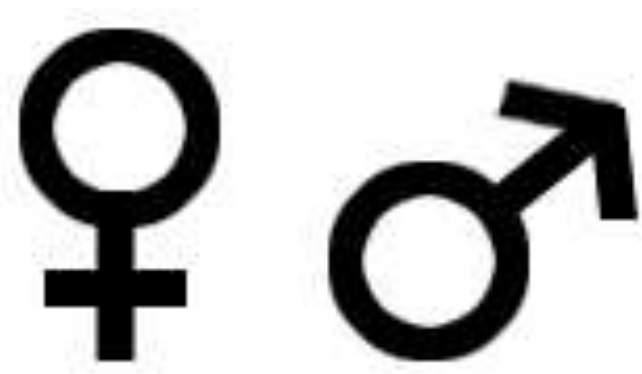

Sumber: Budiman, 2011:80

Gambar 4. Contoh simbol

\section{Hasil Pembahasan}

Lambang negara Indonesia disebut dengan nama Garuda Pancasila. Sebagai lambang negara, Garuda Pancasila dapat disebut sebagai ikon, dimana garuda Pancasila mempunyai hubungan kemiripan dan mewakili dari negara Indonesia.

Bukti dari pernyataan ini dapat dilihat bahwa burung yang digunakan sebagai bentuk dasar dari garuda Pancasila adalah burung garuda yang terdapat pada candi-candi di Indonesia, terutama pulau Jawa.

Beberapa pengamat menyebutkan bahwa terdapat anggapan yang menyebutkan burung garuda hanyalah mitos belaka (Hidayat, 2007). Burung ini tidak dikenal di wilayah geografis Indonesia. Ia dikenal lewat peradaban india yang diambil alih ke dalam peradaban jawa. Ditemukan beberapa artefak penginggalan budaya lampau bermotif garuda, seperti pada Candi Garuda di Candi Wishu, kompleks Candi Prambanan yang menyimpan kisah mistik tentang manusia setengah burung bernama garuda. Pada awalnya lambang negara Indonesia terinspirasi dari mitos garuda yang terdapat di beberapa candi, baik dalam bentuk arca maupun relief.

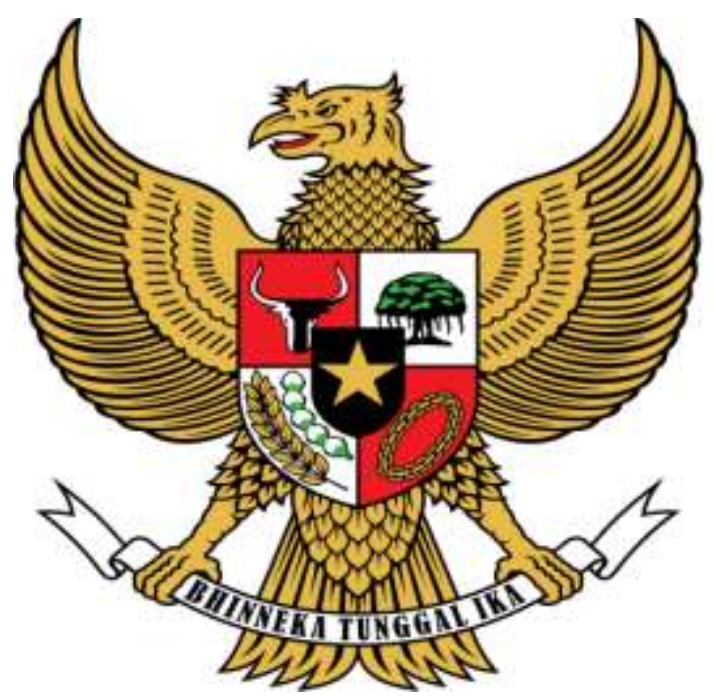

Sumber: http://1.bp.blogspot.com/-r0HRAaJHOrc/TVbVF dMtk8I/AAAAAAAAAA4/Hgw4nyW3OGU/s1600/Garud a+Pancasila.png

\section{Gambar 5. Lambang negara Indonesia}

Penggunaan burung garuda sebagai lambang negara tidak sepenuhnya berdasarkan pada mitologi maupun gambaran yang terdapat pada relief ataupun arca di Candi-Candi di Indonesia. Namun pengambaran burung garuda ini sebenarnya adalah burung elang rajawali. Akmal Sutja, dalam buku Mencari Telur Garuda, menjelaskan bahwa garuda itu adalah istilah yang dipakai dalam mitologi untuk menunjukkan burung elang rajawali, sementara bentuk atau wujud asli atau alamiahnya adalah elang rajawali. Burung garuda dari mitologi menurut perasaan orang Indonesia berdekatan dengan elang rajawali.

Elang jawa (Spizaetus bartelsi) juga disebut sebagai burung nasional Indonesia, karena kemiripannya dengan burung garuda yang menjadi lambang negara Indonesia. Burung ini adalah burung epidemik Jawa berukuran sedang sekitar $60 \mathrm{~cm}$. Dalam bahasa Inggris, elang jawa ini disebut Javan Hawk-eagle, merupakan salah satu jenis burung pemangsa terlangka di dunia (MacKinnon, 1990).

Penggunaan elang sebagai simbol memberikan asosiasi kepada ketinggian, semangat yang membara seperti matahari dan prinsip burung secara umum. Elang adalah burung yang hidup dengan pengaruh matahari secarah menyeluruh, karena itu elang dianggap sebagai bercahaya dalam esensinya dan memiliki elemen udara dan api. Berbeda dengan burung hantu yang dilambangkan dengan kematian dan kegelapan. Sejak elang diidentifikasikan dengan matahari, elang juga dapat menjadi simbol dari ayah (Bapa). Elang secara lebih lanjut dijadikan sebagai simbol dari 
kecepatan dan keberanian untuk terbang lebih tinggi. Elang merupakan raja dari para burung, yang dikenal sebagai simbol dari kekuasaan yang besar dan kegagahan.

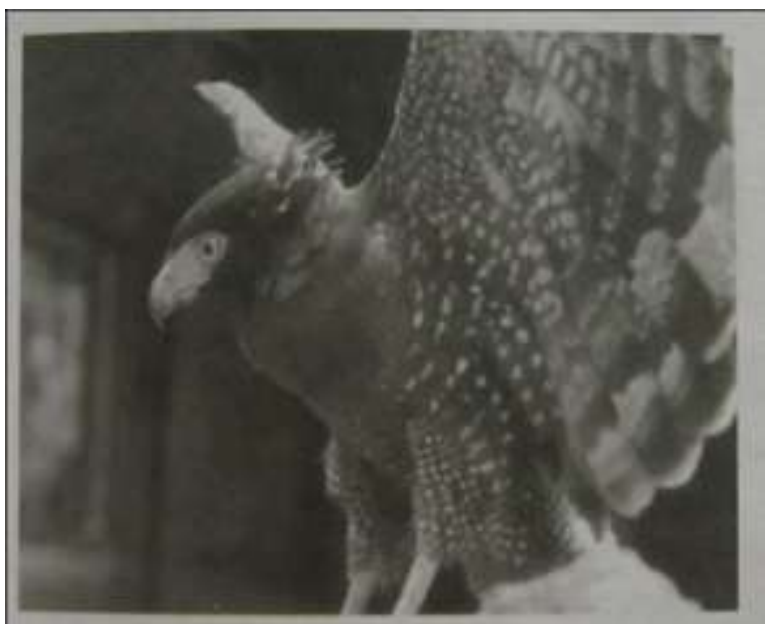

Sumber: Hidayat, 2009: 9

\section{Gambar 6. Spizaetus Bartelsi}

Indonesia memiliki banyak ikon yang dapat mewakili tentang negara Indonesia, seperti penggunaan bahasa Indonesia, kain batik, habitat yang terdapat Indonesia dan lain sebagainya. Sama halnya dengan lambang negara Garuda Pancasila. Garuda Pancasila dapat dikatakan sebagai ikon dari negara Indonesia, pertama adalah dengan adanya penggunaan burung garuda, yang kemudian dikenal dengan burung elang jawa dan telah dinobatkan sebagai maskot satwa langka dari Indonesia pada tahun 1992, yang merupakan habitat asli dari daerah di kawasan Indonesia.

Penggambaran burung garuda pada Garuda Pancasila memiliki spesifikasi, seperti bulu sayap yang berjumlah 17 helai dan bulu ekor 8 helai. Angka yang muncul pada lambang ini memberikan indikasi tentang hari kemerdekaan dari Indonesia, yaitu 17 Agustus atau bulan ke-8. Ketetapan dari jumlah bulu garuda ini dapat ditemukan pada Lampiran Peraturan Pemerintah No. 66 Tahun 1951 pasal 3. Warna yang terdapat pada penggunaan lambang negara Indonesia, yaitu kuning keemasan dapat menjadikannya sebagai indeks. Warna ini memberikan indikasi tentang keinganan negara Indonesia atau visi dan misi Indonesia, yaitu untuk menjadi negara yang bijaksana, agung dan dihormati oleh negara lain. Pernyataan ini dapat ditemukan pada Penjelasan atas Peraturan Pemerintah no.66 Tahun 1951 tentang lambang negara pasal 2 (Hidayat, 2007).

Kepala burung garuda yang menghadap kekanan merupakan sebuah indeks dari sifat baik. Sedang- kan posisi kepala yang lurus merupakan ikon dari sifat negara Indonesia yang tidak ambisius, sombong, semena-mena dan memandang masalah secara lurus. Penggambaran posisi kepala ini dipenggaruhi oleh perancang dari lambang negara, yaitu Pantia Lencana Negara yang didominasi oleh orang Jawa dan dikerjakan di pulau Jawa sehingga tradisi yang digunakan adalah tradisi yang berasal dari pulau Jawa. Di dalam tradisi pewayangan Jawa terdapat tiga istilah tentang posisi kepala. Posisi luruh berarti menunduk ke bawah, longok berarti memandang ke depan, dan langak berarti agak menengadah, memandang agak ke atas. Luruh mempunyai karakter tenang, sabar, tak tergesa-gesa segala tindakannya. Kebalikan dai karakter ini adalah karakter dari posisi langak. Sedangkan posisi longok adalah berada diantara kedua karakter ini (Soekatno, 1992). Secara garis besar tokoh pewayangan di Indonesia dibagi menjadi dua, yaitu tokoh baik dan tokoh jahat. Tokoh baik dapat pula disebut sebagai wayang kanan dan tokoh jahat disebut sebagai wayang kiri. Tokoh baik berada di sebelah kanan dalang dan tokoh jahat berada disebelah kiri dalang. Tokoh kanan selalu menunjukkan sifat-sifat keutamaan, keteladanan bagi manusiamanusia. Pengertian sisi kanan di Indonesia dalam Ensiklopedi Nasional Indonesia adalah dalam politik, merupakan bagian dari ideologi, paham, dan aliran tertentu dalam suatu gerakan politik. Istilah kanan diartikan sebagai sekelompok orang yang duduk di sebelah kanan raja pada sidang pleno kerajaan, dan mereka merupakan kelompok pendukung monarki absolut. Dalam perkembangan selanjutnya, istilah ini mulai dipakai pula oleh negara-negara lainnya. Pada umumnya, kelompok yang berhaluan kanan ini terdiri atas kaum puritan atau bangsawan yang ingin mempertahankan sistem monarki absolut. Sebelah kanan, bagi kebiasaan bangsa Indonesia adalah lambang kebaikan, langkah mujur, kepercayaan, kekuatan. Sedangkan sebelah kiri melambangkan langkah sial, lambang kejahatan dan serong. Kepala garuda yang menoleh lurus ke kanan ini menjadikannya sebagai indeks yang memiliki pengertian bahwa negara Indonesia adalah sebuah negara yang tidak tergesa-gesa ataupun ambisius dalam mengambil keputusan dan melihat permasalah secara lurus. Selain itu negara Indonesia juga merupakan negara yang memiliki kepercayaan, kebaikan serta kekuatan untuk menjadi negara yang besar.

Penggambaran kaki garuda pada lambang negara Indonesia, Garuda Pancasila, digambarkan dari sisi depan. Ini merupakan hasil rancangan akhir yang akhirnya disahkan pada tahun 1951. Pada awalnya, kaki garuda digambarkan dari sisi 
belakang. Penggambaran ini merupakan gambaran dari semi-realis burung elang jawa saat mencengkeram makanan atau mangsanya. Namun, kemudian Bung Karno memerintahkan pengubahan pada bentuknya hingga seperti sekarang ini. Alasan dari pengantian bentuk kaki ini menurut Presiden Soekarno adalah karena berkaitan dengan prinsip dari jati diri bangsa Indonesia yang memadukan pandangan federalis dan pandangan kesatuan. Selain itu, menurut Bung Karno penggambaran kaki dari depan dapat menampilkan kesan yang lebih. Penggambaran kaki Garuda Pancasila sedemikian rupa dapat menjadikannya sebagai indeks dari kesan gagah yang inginkan Bung Karno gagah (Sahabat Museum Konfernsi Asia-Afrika, 2011).

Pita yang dicengkeram oleh kaki burung garuda menggunakan warna putih yang merupakan indeks dari kejujuran, kebijaksanaan dan kedamaian. Tulisan yang terdapat pada pita merupakan kalimat dari bahasa Sansekerta. "Bhinneka Tunggal Ika" yang tertulis pada pita yang dicengkeram burung garuda merupakan sebuah seloka yang berasal dari Kitab Sutasoma yang dikarang oleh Empu Tantular, yang artinya adalah: Meskipun berbeda-beda tetapi satu jua. Hal tersebut melambangkan bersatunya keanekaragaman ras, suku, adat-istiadat, budaya, bahasa dan agama yang dimiliki bangsa Indonesia dari Sabang sampai ke Merauke, ke dalam negara Kesatuan Republik Indonesia. Di dalam Penjelasan atas Peraturan Pemerintah no.66 Tahun 1951 tentang lambang negara pasal 5 dijelaskan tentang semboyan ini. Penulisan kalimat "Bhinneka Tunggal Ika" pada pita yang dicengkeram di kaki burung garuda merupakan sebuah indeks pada lambang negara Garuda Pancasila. Indeks ini mengartikan bahwa bangsa Indonesia terdiri dari berbagai macam suku atau ras. Namun dengan adanya perbedaan ini tidak membuat negara Indonesia menjadi terpecah belah, tetapi menjadikan sebuah negara yang bersatu baik dalam tujuan maupun kehidupan bernegara.

Pada dada Garuda Pancasila terdapat sebuah perisai. Perisai yang berada di dada burung garuda ini merupakan sebuah ikon sekaligus indeks. Perisai merupakan sebuah ikon karena perisai di dada burung garuda memiliki kemiripan dengan bentuk perisai pada umumnya. Sedangkan indeks adalah karena perisi pada lambang negara Indonesia memiliki indikasi sebagai sebuah senjata untuk melindungi negara dari pengaruh atau dampak negatif yang akan masuk ke dalam negara Indonesia. Perisai adalah tameng, merupakan alat kelengkapan perang prajurit jaman dulu yang berfungsi melindungi tubuh dari serangan senjata tajam lawan dalam perang.

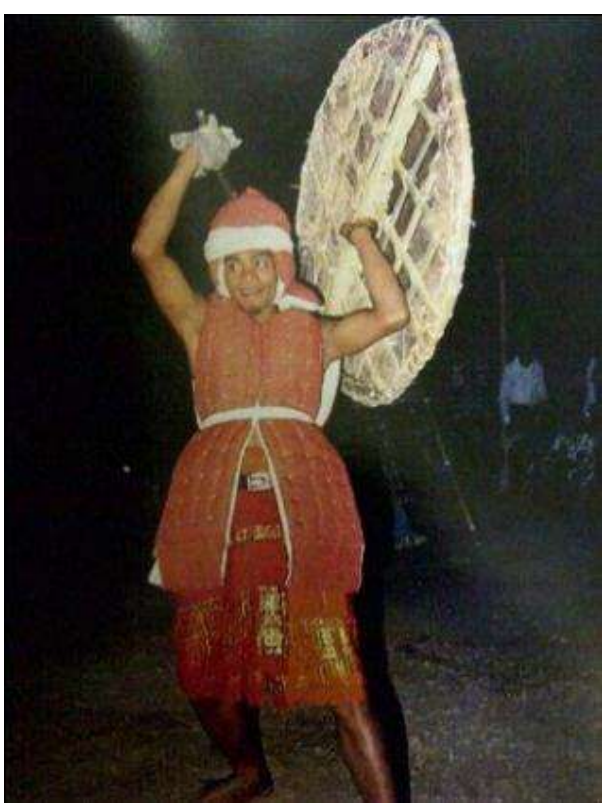

Sumber: Ensiklopedi Nasional Indonesia; 70

Gambar 7. Perisai yang digunakan di Indonesia

Di dalam Penjelasan atas Peraturan Pemerintah no.66 Tahun 1951 tentang lambang negara pasal 4 dijelaskan tentang penggunaan perisai atau temeng pada lambang negara. Pada perisai yang berada di dada burung garuda terdapat 3 warna yang berbeda, yaitu merah, putih dan hitam. Ketiga warna ini merupakan indeks yang memiliki arti yang berbeda antara yang satu dan yang lain. Warna merah menandakan semangat dan keberanian. Warna merah di sini sama dengan penggunaan warna merah pada bendera nasional Indonesia, yaitu untuk melambangkan keberanian. Sama halnya dengan warna putih, warna ini merupakan warna yang sama yang digunakan dalam bendera nasional Indonesia. Warna putih memberikan arti tentang kejujuran, kebijksanaan, kesucian dan kesempurnaan. Sedangkan warna hitam memberikan kesan kemakmuran, keeleganan, kekuatan, kesungguhan dan kerendahan hati.

Perisai yang terdapat di dada burung garuda merupakan perisai yang melambangkan Pancasila. Penggunaan perisai Pancasila dalam lambang negara Indonesia merupakan ide dari Presiden Soekarno. Beliau mengatakan bahwa hendaknya lambang negara mencerminkan pandangan hidup bangsa, dasar negara Indonesia, di mana sila-sila dari dasar negara, yaitu Pancasila divisualisasikan dalam lambang negara. Di dalam perisai terbagi menjadi lima bagian yang merupakan ikon tiap sila dari Pancasila. Penataan bagian dari sila-sila disusun sedemikian rupa, karena kelima sila dari Pancasila saling berhubungan dan merupakan sebuah kesatuan dari pandangan hidup bangsa Indonesia. Peletakan sila pertama berada di 
tengah karena bintang, yang merupakan ikon dari sila pertama, memiliki empat sudut yang menunjuk keempat sila lainnya, karena setiap sila-sila dalam Pancasila harus selalui dijiwai oleh Ketuhanan Yang Maha Esa. Menurut Moh. Hatta sebagai orang yang terlibat dalam perumusan Pancasila, berpendapat bahwa dengan adanya Ketuhanan Yang Maha Esa, barulah bangsa dapat bertahan maju ke depan untuk membangun generasi penerus yang bermartabat dan berprikemanusiaan, yang digambarkan dengan sila kedua. Setelah itu membangun persatuan Indonesia, karena hanya dengan bersatu dan perpaduan bangsa Indonesia menjadi kuat dan langkah berikutnya adalah membangun negara yang demokratis dalam permusyawaratan/ perwakilan. Sehingga secara bersama-sama bangsa Indonesia dapat mewujudka keadilan sosial bagi seluruh rakyat Indonesia. Menurut salah satu perancang dari lambang negara, yaitu Sultan Hamid II, menjelaskan bahwa konsep yang digunakan adalah "Thawaf" yang berarti gilir balik. Maksud dari konsep yang digunakan Sultan Hamid II ini adalah perisai dari Garuda Pancasila dibaca dari tengah, kemudian melingkar dari simbol rantai melawan arah jarum jam. Thawaf merupakan istilah yang digunakan pada ide pacasila, yaitu mengikuti gerakan yang berlawan arah dengan jarum jam. Thawaf ini merupakan istilah yang berasal dari bahasa Kalimantan, yang berarti membuat kembali membangun/ vermogen yang ada tujuannya pada sasaran yang jelas, yaitu masyarakat adil dan makmur yang berdampingan dengan rukun dan damai.

Sila pertama dalam Pancasila berbunyi Ketuhanan yang Maha Esa. Sila ini digambarkan dengan sebuah ikon dari bentuk bintang yang memiliki 5 sudut. Bintang menurut pemikiran kuno melambangkan sebagai simbol dari harapan, keberuntungan atau keabadian. Bintang digunakan sebagai ikon dari sila pertama adalah karena bintang dapat melambangkan sifat-sifat dari Tuhan, selain letaknya tinggi di angkasa cahayanya menyinari alam raya. Hal ini melambangkan sifat-sifat Tuhan yang diyakini bangsa Indonesia, selain Tuhan Yang Maha Esa, Maha Tinggi, Maha Pemurah dan Pengasih, Maha Kuasa dan Maha Bijaksana. Bintang ini terletak dalam sebuah perisai kecil-hitam, melambangkan bahwa berketuhanan Yang Maha Esa itu jelasnya menurut ajaran agama masing-masing yang dianut/ diyakini, bahwa agama itu ibarat perisai, lambang pertahanan agar manusia dapat selamat hidup di dunia dan di akhirat kelak. Warna kuning yang digunakan sebagai warna dari bintang merupakan warna asli dari bintang. Warna ini merupakan indeks dari penerangan, kemurahan hati dan ketuhanan.
Pada bagian kanan bawah perisai terukir gambar rantai. rantai merupakan rangkaian gelang yang saling bertautan, dalam berbagai bentuk dan dari bermacam-macam bahan, untuk berbagai kegunaan. Rantai mempunyao banyak ukuran, dari yang sangat kecil, misalnya rantai kalung untuk perhiasan, sampai rantai yang sangat besar, misalnya rantai jangkar kapal. Rantai secara umum merupakan sebuah simbol persatuan, pengikat atau efek rantai yang misterius dan propaganda. Ketika sebuah rantai terhubung antar ujungnya maka akan menjadi sebuah simbol dari keabadian. Secara umum simbol rantai mengimplikasikan tentang ingatan dan komunikasi. Dalam artian yang lebih luas lagi, rantai berhubungan dengan simbol dari ikatan dan pertalian, jalinan dan ikatan.

Sila kedua dalam Pancasila berbunyi Kemanusian yang adil dan beradab. Sila ini digambarkan dengan bentuk ikon rantai yang terdiri dari 8 rantai persegi, dan 9 rantai bundar. Rantai persegi dan rantai bundar merupakan ikon dari laki-laki dan perempuan. Rantai yang terdiri atas dua bentuk persegi dan lingkar, melambangkan umat manusia sebagai makhluk Tuhan terdiri dari dua jenis: pria dan wanita. Sedangkan cincin wujudnya lingkaran tak berpangkal dan tak berujung melambangkan ikatan abadi, lambang hubungan keluarga pria-wanita turun-temurun, tiada putusputusnya serta lambang hubungan umat manusia di seluruh dunia adalah keturunan Adam dan Hawa serta satu sama lain bersaudara. Di dalam Penjelasan atas Peraturan Pemerintah no.66 Tahun 1951 tentang lambang negara pasal 4 dijelaskan tentang ikon dari sila kedua tersebut. Warna pada rantai menggunakan warna kuning yang merupakan indeks dari kejujuran, adil dan bermoral.

Pohon adalah salah satu simbol tradisional yang paling esensial. Tidak jarang simbol pohon digunakan secara umum walaupun terkadang beberapa orang menggunakan spesies pohon secara khusus. Dalam arti yang paling umum, simbolisme pohon menunjukkan kehidupan kosmos, yaitu konsistensi, pertumbuhan, proliferasi, generatif dan proses regeneratif. Singkatnya pohon melambangkan kehidupan yang tak ada habis-habisnya, dan karena itu dianggap sebagai simbol keabadian. Pohon menjadi simbol dari realitas yang absolut, yaitu pusat dunia. Karena pohon memiliki bentuk panjang dan vertikal, simbolisme pusat dari dunia dinyatakan dengan sumbu axis atau sumbu yang mengarah ke atas atau vertikal. Pohon yang akarnya berada di bawah tanah dan cabangcabangnya naik ke langit, melambangkan kenaikan. 
Pohon beringin pada perisai terletak pada bagian kanan atas. Sila ketiga dalam Pancasila berbunyi Persatuan Indonesia. Sila ini dilambangkan dengan ikon pohon beringin. Pohon beringin melambangkan persatuan Indonesia, lambang kebangsaan/ nasionalisme patriotisme Indonesia, karena pohon beringin terdapat di seluruh tanah air kita, pohon yang besar kokoh akarnya menghuma dan dahan serta daunnya rindang dapat dipakai tempat berteduh dan berlindung, melukiskan tempat perumahan bangsa-negara, tempat bernaung sebagai rumah-tangga besar bangsa Indonesia. Warna yang ditentukan untuk ikon dari sila ketiga ini adalah pohon beringin dengan warna hijau dan kontur hitam. Warna hijau dan hitam pada gambar pohon beringin ini merupakan sebuah indeks. Warna hijau untuk menandakan kesuburan, kehidupan, harapan, kesegaran dan keberuntungan. Sedangkan warna hitam menunjukkan kekuatan, kesuburan tanah dan kemakmuran, selain sebagai pemberi kesan tiga dimensi pada pohon beringin.Pada bagian kiri atas perisai terdapat gambar kepala banteng.

Dalam berbagai budaya, banteng merupakan simbol dari suatu kepentingan yang besar. Banteng memiliki kekuatan yang sangat besar dan hebat sehingga banteng merupakan simbol dari kekuatan dan semangat. Tanduk dari banteng dapat melambangkan bulan sabit, karena bentuk tanduk yang mirip dengan bentuk dari bulan sabit.

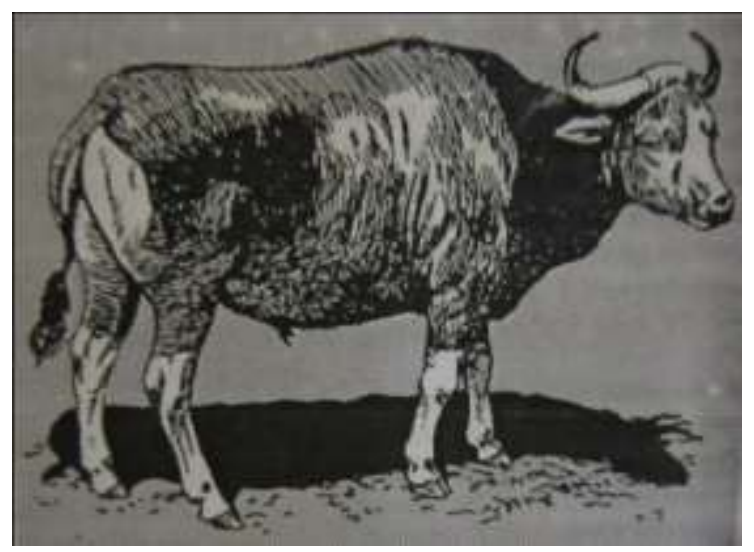

Sumber: Ensiklopedi Nasional Indonesia, 162

Gambar 8. Banteng

Sila keempat pada Pancasila berbunyi kerakyatan yang dipimpin oleh hikmat kebijaksanaan dalam permusyawarahan/perwakilan.

Sila ini menggunakan ikon dengan bentuk kepala banteng. Kepala banteng, lambang dari sila keempat atau prinsip Kedaulatan Rakyat dalam Negara Hukum yang Demokratis, karena banteng terdapat sebagai salah satu binatang (fauna) Indonesia dan binatang yang kuat serta tangkas, tak mau mengganggu, tapi apabila dia diganggu/ dilukai akan berontak/mengamuk. Hal ini melambangkan kekuatan, kedaulatan rakyat Indonesia seluruhnya atas Negara RI yang gagah berani karena kebenaran. Warna yang digunakan dalam ikon kepala banteng adalah warna hitam dan putih. Selain untuk memberikan kesan tiga dimensi kedua warna ini memiliki indeks yang lain. Warna putih memberikan indeks tentang kejujuran, kebijaksanaan dan kedamaian. Sedangkan warna hitam sebagai indeks memberikan kesan kuat, martabat, kesungguhan dan kerendahan hati.

Sila kelima dan terakhir dalam Pancasila berbunyi keadilan sosial bagi seluruh rakyat Indonesia. Sila ini dilambangkan dengan ikon padi dan kapas. Padi adalah simbol dari seluruh bangsa tentang kebahagian, harapan, panen dan kelimpahan. Padi dan kapas merupakan tanaman yang terdapat dan hidup subur di tanah air Indonesia. Padi melukiskan pangan, makanan pokok orangorang Indonesia, sedangkan kapas melukiskan bahan pakaian rakyat Indonesia. Padi dan kapas melambangkan sandang dan pangan, merupakan bahan kemakmuran lahiriah sebagai sarana kemakmuran batiniah, padi dan kapas melambangkan keadilan dan kemakmuran seluruh rakyat Indonesia yang menjadi tujuan Bangsa dan Negara RI (Hidayat, 2007). Di dalam Penjelasan atas Peraturan Pemerintah no.66 Tahun 1951 tentang lambang negara pasal 4 dijelaskan tentang ikon dari sila terakhir ini. Warna yang terdapat pada ikon terakir Pancasila ini adalah warna putih, hijau dan kuning. Warna-warna ini merupakan indeks yang terdapat pada gambar padi dan kapas ini. Warna hijau pada gambar ini memberikan indikasi tentang kesuburan, kesegaran dan kehidupan. Warna putih memberikan indikasi tentang kedamaian dan kesempurnaan. Yang terakhir adalah warna kuning yang memberikan indikasi tentang warna dari padi yang matang.

Garuda Pancasila yang merupakan nama dari lambang negara Indonesia secara keseluruhan termasuk dalam simbol. Simbol adalah menyatakan tentang hubungan tanda secara konvensi. Di Indonesia, Garuda Pancasila telah diresmikan dan ditetapkan oleh Presiden Soekarno pada tahun 1951. Sehingga telah ada hukum yang secara tertulis menjelaskan tentang Garuda Pancasila sebagai lambang negara Indonesia. Ketetapan tentang Garuda Pancasila sebagai lambang negara dapat dilihat pada Undang-Undang Dasar Negara Republik Indonesia Bab XV Pasal 36a . 
Lambang negara Romania menggunakan figur burung sebagai bentuk dasarnya. Burung inilah yang menjadi ikon dari negara Romania. Simbol nasional dari negara Romania adalah burung yang dijadikan sebagai lambang negara, yaitu golden eagle. Golden eagle dalam bahasa biologi atau bahasa ilmiah disebut dengan Aquila chrysaetos.

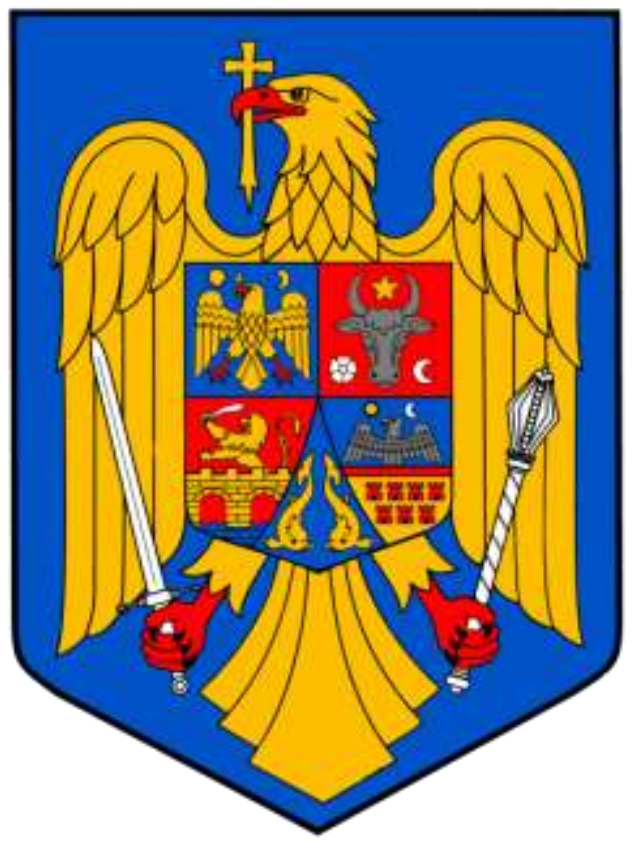

Sumber: http://paulrinder.files.wordpress.com/2010/06/ 2000px-coat_of_arms_of_Romania_svg.png

Gambar 9. Lambang negara Romania

Dalam mitologi yang paling terkenal di dunia, yaitu Yunani, terdapat penggambaran tentang burung aquila ini (Souli, 1995; Mangoenrahardjo, 1976). Burung ini merupakan hewan peliharan dari penguasa langit, dewa Zeus. Burung rajawali emas milik Zeus ini diberi nama Aquila. Burung elang emas ini dalam negara Romania dijadikan sebagai lambang dari hirarki pertama yang mana merupakan sebuah ikon.

Burung Elang memberikan indikasi tentang keberanian, tekad, yang membubung tinggi keangkasa, kekuasaan, dan kemegahan. Warna yang digunakan dalam burung dalam lambang negara Romania adalah warna kuning keemasan. Warna ini merupakan sebuah indeks. Warna kuning keemasan ini mendindikasikan negara Romania sebagai negara yang bijaksana, jujur dan penuh semangat. Sedangkan warna yang latar belakang burung, yaitu warna biru merupakan sebuah indeks juga. Warna biru sebagai indeks memberikan arti bahwa negara Romania adalah negara yang religius, memiliki hati yang teguh, tenang dalam berpikir dan memiliki keadilan (Peterson, 2000).

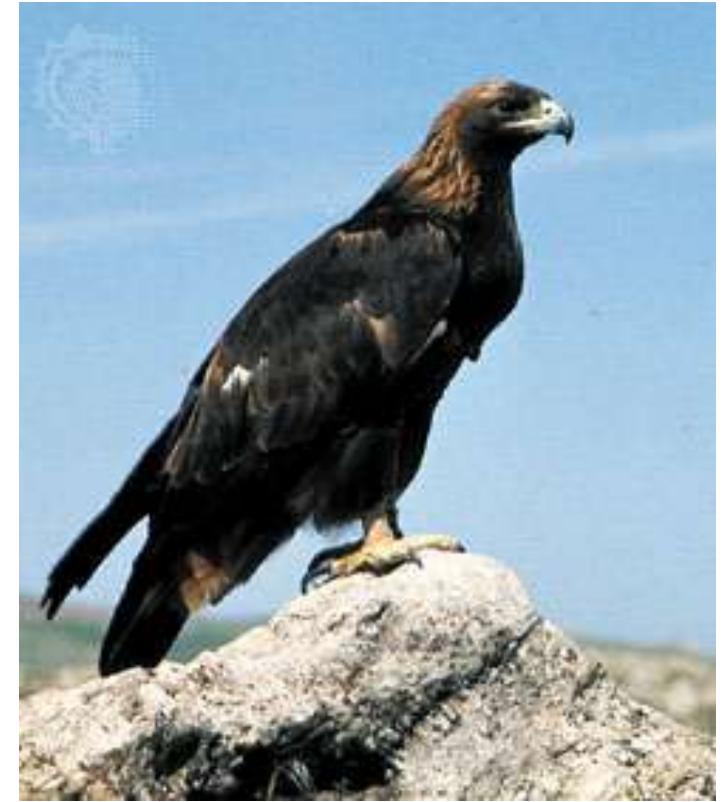

Sumber: http://www.britannica.com/EBchecked/topic/ 237588/golden-eagle

Gambar 10. Elang emas

Kepala burung yang menghadap kanan dalam lambang negara Romania merupakan sebuah indeks. Sisi kanan ini memberikan indikasi tentang sisi yang baik dan sisi kiri adalah sisi yang jelek. Hal yang sama pula dalam konteks politik, kanan merupakan sisi yang baik atau benar. Persepsi ini dimulai pada parlemen revolusioner di Perancis. Bagi negara Romania, kepala burung yang menghadap kanan memberikan indikasi tentang arah kebaikan dan dapat memberikan kemajuan untuk negara mereka. Lambang salib merupakan tanda yang mewakili segala sesuatu yang berhubungan dengan keagamaan terutama Tuhan Yesus dan menggambarkan salib pada saat Tuhan Yesus disalibkan. Selain itu lambang salib memberikan indikasi tentang agama mayoritas yang dianut oleh rakyat Romania dan kehidupan sehari-hari berdasarkan pada aturan-aturan keagamaan. Salib yang diletakkan pada mulut atau paruh burung adalah untuk memberikan indikasi tentang segala tingkah laku dan perkataan dari bangsa Romania bedasarkan pada aturan agama yang dianutnya (The World Factbook 2011, 2011).

Pedang yang oleh bangsa Romania disebut dengan saber (salah satu jenis pedang) merupakan ikon yang mewakili pemersatu Moldavia yaitu Stephen the Great (1456-1504) atau juga disebut sebagai "Christ's athlete", selain hubungan mewakili pedang juga memiliki hubungan kemiripan bentuk. Pedang juga dapat dikatakan sebagai indeks, karena pedang memberikan indikasi tentang kekuatan dan senjata untuk mempertahankan diri. 


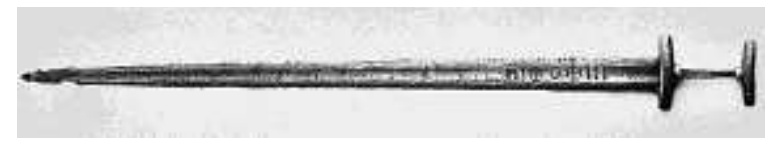

Sumber: http://www.britannica.com/EBchecked/topic/ 577385/sword

\section{Gambar 11. Pedang}

Pada lambang negara Romania tongkat yang disebut sebagai scepter merupakan ikon yang mewakili Michael The Brave, yang merupakan pemersatu pertama negara Romania dan memiliki kemiripan bentuk dengan bentuk scepter pada umumnya. Selain itu scepter atau tongkat kerajaan yang digunakan pada kaki kiri burung merupakan indeks dari ketaatan, kedaulatan dan kekuasaan yang nyata (McNab, 2010).

Perisai berperan sebaik ikon dan indeks. Perisai memberikan indikasi tentang sebuah senjata yang digunakan untuk melindungi, dalam hal ini perisai berperan untuk melindungi negara saat terjadi hal-hal negatif di luar sana (Regan, 2006).

Pada bentukan perisai yang terbagi ke dalam 5 bagian merupakan ikon dari negara-negara bagian atau propinsi di Romania. Negara bagian dari Romania antara lain adalah Wallachia, Moldavia, Transylvania, Banat serta ikon yang terakhir mewakili Romania sebagai negara yang berbatasan dengan Black Sea.

Ikon dari negara Wallachia ini digambarkan dengan bentuk elang yang menyerupai lambang negara Romania, yaitu elang dengan paruh menggigit salib. Namun dalam gambar ini tidak digambarkan perisai di dada serta pedang dan tongkat seperti yang terdapat pada lambang negara Romania. Kemudian, ditambahkan gambar matahari di sebelah kanan dan bulan sabit di sebelah kiri burung. Pada sebelah kanan burung terdapat gambaran dari matahari. Matahari disini dapat merupakan sebuah ikon maupun indeks. Pengambaran matahari digambarkan sebagaimana bentuk asli dan menyerupai matahari. Matahari sebagai indeks memberikan pengertian tentang kehangatan dan sebuah awal baru. Pada sebelah kiri burung terdapat gambaran dari bulan sabit. Sama halnya dengan matahari, gambar bulan sabit dalam ikon Wallachia merupakan sebuah ikon dan indeks. Bulan sabit mengartikan tentang kekuatan yang mengagungkan yang dimiliki oleh perasatuan dari propinsi Wallachia (Biedermann, 1992; Cirlot, 1971).

Kerbau dalam gambaran propinsi Moldavia merupakan sebuah ikon, digambarkan menyerupai bentuk aslinya. Kerbau sebagai indeks berperan untuk memberikan sifat kerendahan hati, rela berkorban dan cinta kedamaian.

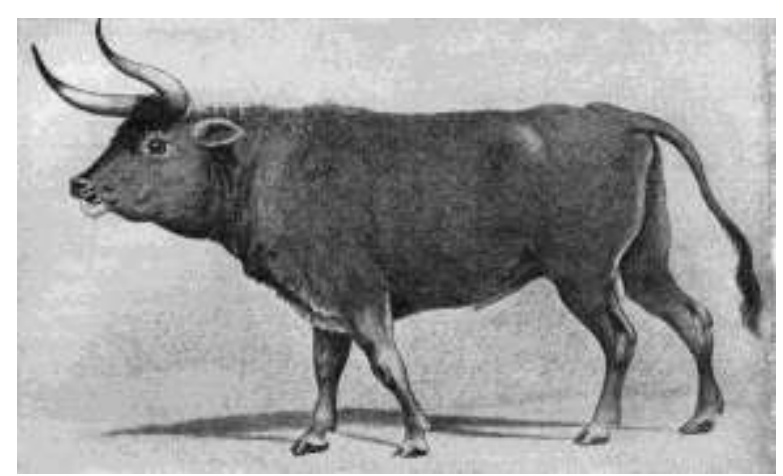

Sumber: http://mycattleworld.blogspot.com/2011/06/waythings-were.html

Gambar 12. Kerbau

Bintang yang berada diantara tanduk kerbau merupakan sebuah ikon dari bentuk tradisonal bintang, yaitu dengan sudut lima. Bintang dengan sudut lima memberikan indikasi tentang kekuatan untuk dapat menjadi lebih baik. Selain itu bintang juga memberikan pengertian sebagai penerangan dalam kegelapan. Cinquefoil pada gambar propinsi Moldavia merupakan sebuah ikon dari bentuk cinquefoil pada umunya. Cinquefoil sebagai indeks memberikan pengertian tentang sebuah pencapaian yang diinginakan oleh Moldavia.

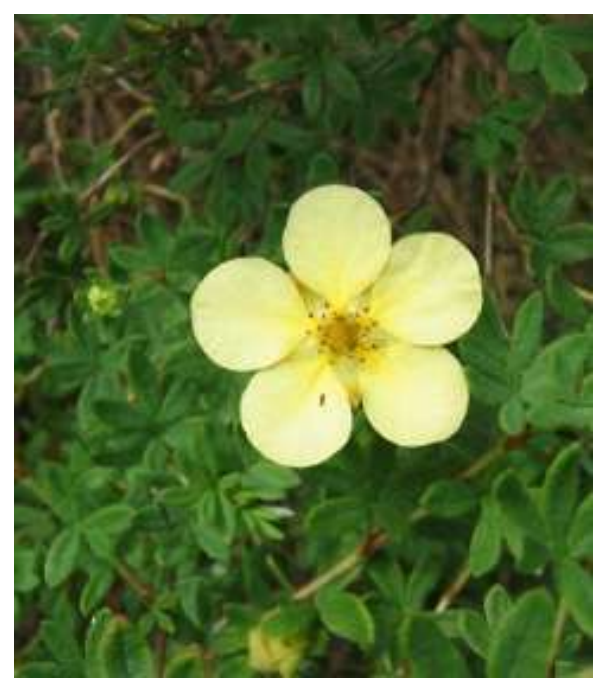

Sumber: http://www.britannica.com/EBchecked/topic/118 167/cinquefoil

\section{Gambar 13. Cinquefoil}

Pada ikon negara Banat singa perperan untuk memberikan arti bahwa binatang singa adalah penguasan hutan dengan karakteristik yang penuh keberanian dan kekuatan yang besar. Pedang berperan untuk menampilkan kekuatan yang dimiliki oleh ikon singa. Pedang yang digunakan pun bukan jenis pedang biasa, tetapi 
jenis pedang yang lebih besar dan dapat menimbulkan kerusakan lebih parah dari jenis pedang biasanya. Jembatan merupakan sebuah indeks untuk penyebarangan atau perubahan, yaitu untuk menghubungkan dua tempat yang berbeda atau untuk membuat terjadinya sebuah perubahan yang diinginkan.

Burung yang dijadikan ikon oleh propinsi Transylvania adalah burung yang sama dengan yang ada pada lambang negara Romania. Benteng yang terdapat pada ikon dari propinsi Transylvania merupakan sebuah ikon yang memiliki bentuk serupa dengan benteng yang dibangun pada jaman dahulu. Jumlah benteng yang digambarkan pada ikon propinsi Transylvania adalah 7 buah. Pengambaran 7 benteng ini merupakan ikon dari gereja berbenteng yang terdapat di propinsi Transylvania.

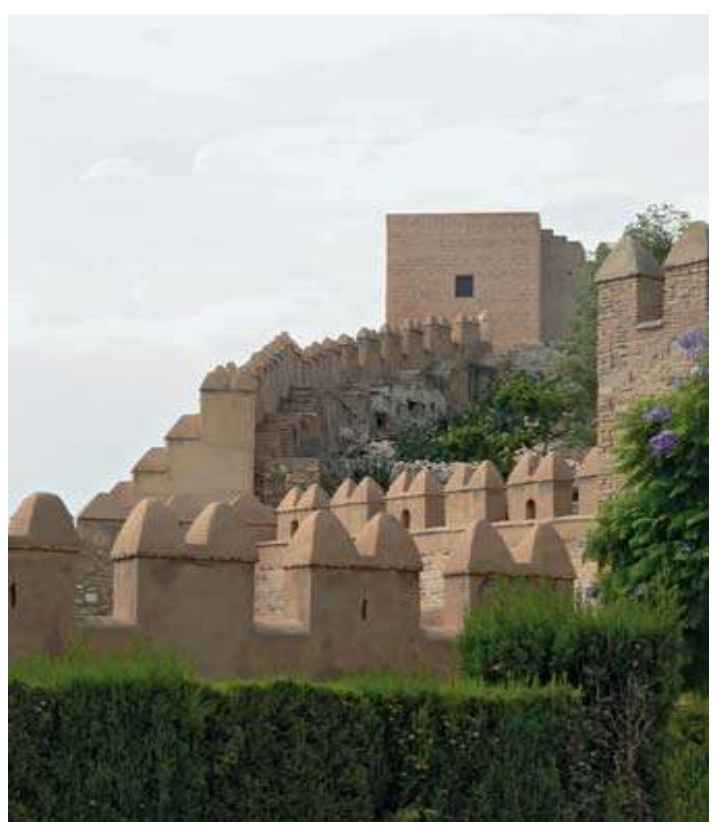

Sumber: http://www.britannica.com/EBchecked/topic/ 56259/battlement

\section{Gambar 14. Benteng}

Benteng dalam bentuk primitifnya melambangkan kekuatan dan kekuasaaan. Makna ini terus bertahan pada bentuk modern dari gedung pencakar langit, tinggi bangunan lebih sering dibanggakan daripada efisiensi atau bentuknya.

Lumba-lumba pada lambang daerah sekitar Laut Hitam merupakan ikon dari bentuk lumba-lumba pada kenyataannya. Lumba-lumba disini berperan sebagai indeks, yaitu untuk memberikan penyelamatan kepada yang membutuhkan, serta memiliki keamanan dan kebahagiaan. Penggambaran lumba-lumba dengan posisi terbalik untuk memberikan pengertian bahwa lumbalumba memiliki sesutu hal yang ajaib yang dapat digunakan untuk membantu manusia (Achen, 1978; Encyclopædia Britannica Online).

Lambang negara Uni Emirat Arab merupakan sebuah ikon yang mewakili negara Uni Emirat Arab. Burung yang digunakan oleh Uni Emirat Arab sebagai lambang negara adalah golden falcon. Falkon, adalah burung pemangsa siang hari berukuran sedang, kebanyakan termasuk genus Falco, famili Falconidae. Falkon termasuk burung yang paling elok dan sangat tinggi tingkat evolusinya.

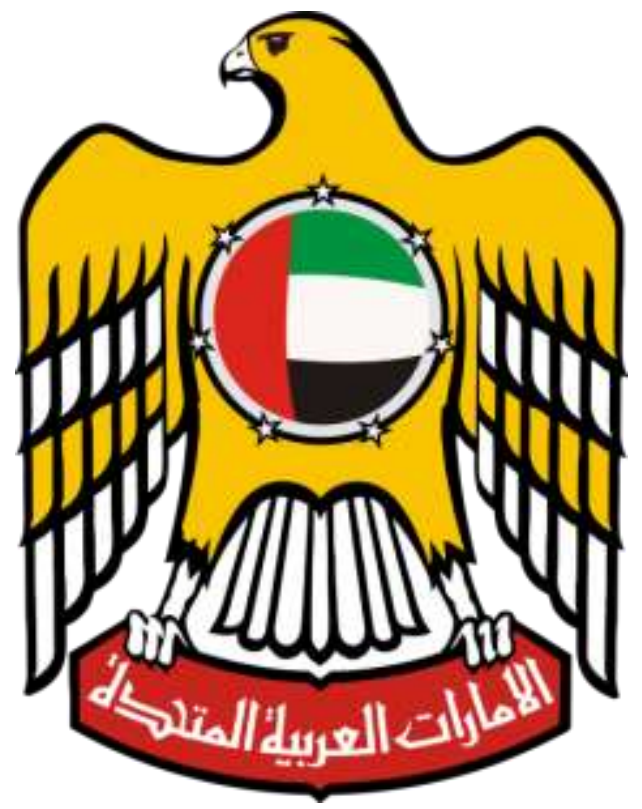

Sumber: http://rlv.zcache.com/uae_coat_of_arms_detail_ posterrc561f0bc5a3745cb828c874d90195bcb_j0e_400.jpg

\section{Gambar 15. Lambang negara Uni Emirat Arab}

Falkon dalam mitologi Mesir sering disebut dengan nama Horus. Horus, dalam agama Mesir kuno adalah dewa dalam bentuk falkon dimana mata kanannya adalah matahari atau bintang fajar yang mewakili kekuasaan dan intisari, sedangkan mata yang kiri adalah bulan atau bintang senja, yang mewakili penyembuhan. Dalam Mesir Kuno, falkon (terutama peregrine) adalah simbol kerajaan, karena pandangan mata dari burung falkon ini dapat melumpuhkan burung lain seperti pandangan firaun kepada musuh-musuhnya. Falkon atau hawk adalah perwujudan Horus, dewa besar dari langit (Encyclopædia Britannica Online) . Falkon sebagai lambang negara Uni Emirat Arab memberikan indikasi tentang burung dengan kekuatan besar yang dapat memberikan perubahan ke arah yang lebih baik bagi negara Uni Emirat Arab. 

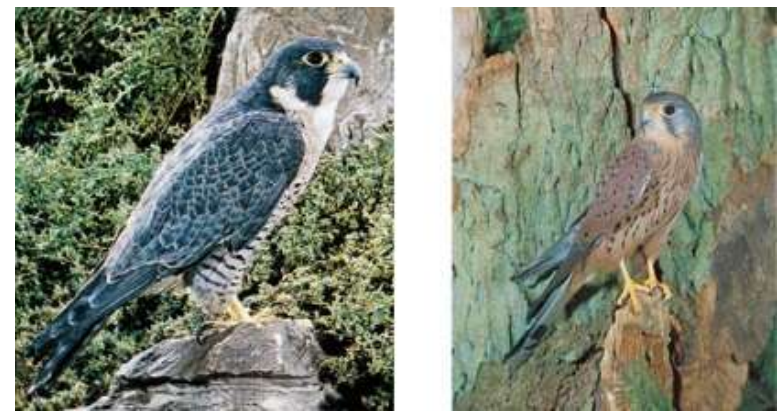

Sumber: http://www.britannica.com/EBchecked/topic/ 200679/falcon

Gambar 16. Falkon

Penggunaan warna kuning keemasan pada warna burung falkon untuk menjadikan burung falkon sebagai burung yang memiliki kehormatan dan keagungan. Selain itu digunakan unsur warna putih untuk menampilkan citra kebijaksanaan dan keadilan.

Kepala burung falkon yang menoleh ke kanan secara politik memberikan indeks tentang sisi yang lebih baik dan negara Uni Emirat Arab menginginkan hal baik saja yang terjadi pada pemerintahan negaranya. Parlemen revolusioner Perancis memberikan dampak mendunia tentang pandangan politik ini, dalam hal sisi kanan sebagai sisi yang baik dan sisi kiri adalah sisi yang kurang baik.

Pada lambang negara Uni Emirat Arab, bagian kaki burung digambarkan dengan mencengkeram sebuah pita dengan tulisan bahasa Arab. Bahasa Arab adalah bahasa Qur'ān, kitab suci Islam dan bahasa ini merupakan bahasa agama dari seluruh umat Islam. Tulisan berbahasa Arab ini merupakan ikon yang menggambarkan tulisan bahasa Arab. Serta untuk mewakili sebagai negara yang beragamakan Islam. Tulisan berbahasa Arab

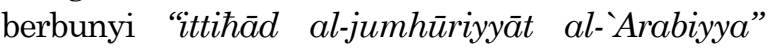

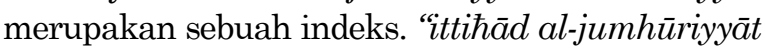
al-Arabiyya" dalam bahasa Indonesia berartikan federasi republik Arab, yang memberikan pengertian bahwa Uni Emirat Arab adalah negara yang telah merdeka (The World Factbook 2011, 2011).

Pada lambang negara Uni Emirat Arab bagian dada burung falkon terdapat perisai yang berbentuk lingkaran. Perisai merupakan perlengkapan perang yang pada umumnya dipegang pada tangan kiri yang digunakan untuk melindungi diri dari serangan musuh. Di sekitar lingkaran pada perisai terdapat bintang berjumlah tujuh buah. Bintang adalah indeks dari penerangan saat terjadi kegelapan. Angka tujuh merupakan simbolisasi dari tatanan kesempurnan atau siklus yang lengkap. Jumlah 7 pada gambaran bintang merupakan ikon yang mewakili 7 emirat yang ada pada negara Uni Emirat Arab Jumlah tujuh ini memberikan indikasi tentang kesempurnaan.
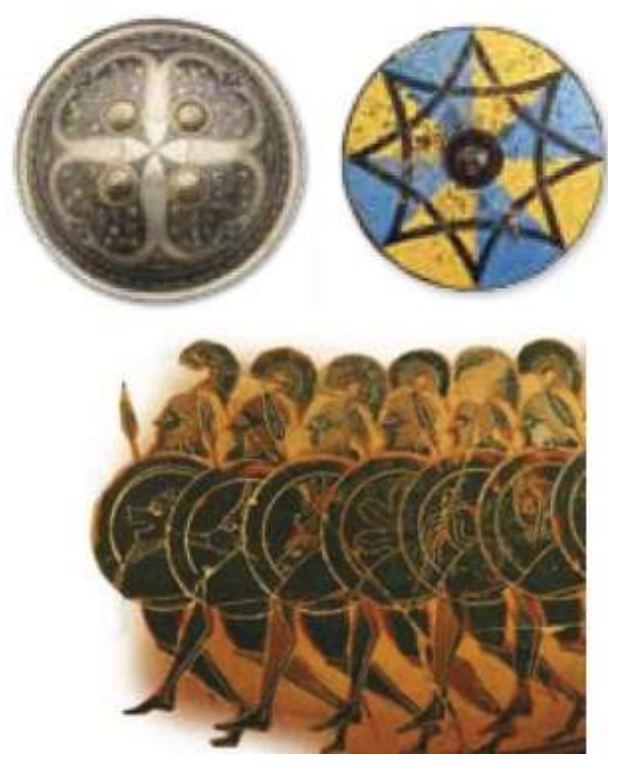

Sumber: Regan, 2006

Gambar 17. Perisai bulat

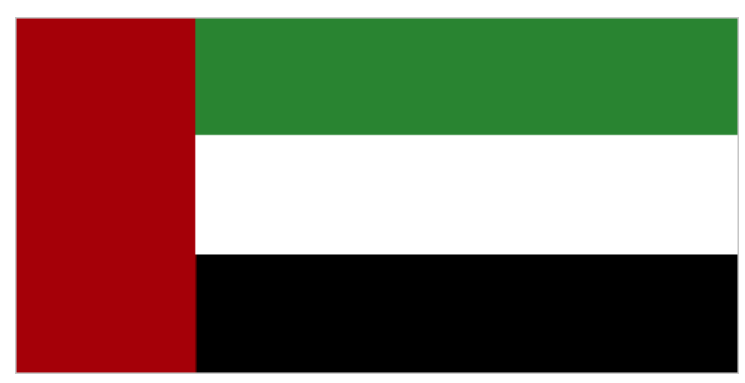

Sumber: https://www.cia.gov/library/publications/the-worldfactbook/flags/flagtemplate_ae.html

Gambar 18. Bendera Uni Emirat Arab

Warna perisai digunakan dalam lambang negara Uni Emirat Arab adalah perpaduan warna dari bendera nasional Uni Emirat Arab. Kenyataan bahwa bendera selalu ditempatkan di atas sebuah tiang ini mengekspresikan keangkuhan atau keinginan untuk memberatkan makna spiritual dari benda dengan meletakkannya di posisi yang lebih tinggi. Bendera memiliki peran sebagai tanda kemenangan dan pernyataan diri. Warna merah dari bendera yang terdapat di dada burung merupakan indeks dari keberanian negara dalam melawan penjajahan yang terjadi, semangat dan kekuatan serta kesatuan. Di dalam agama Islam, warna hijau adalah warna Nabi. Warna hijau pada bendera Uni Emirat Arab memberikan indikasi tentang tanah atau lahan dari negara Uni 
Emirat Arab yang subur, harapan, kebahagian dan kegembiraan. Warna putih pada bendera Uni Emirat Arab memberikan indikasi tentang kedamaian dan kejujuran.Warna hitam pada bendera Uni Emirat Arab memberikan indikasi tentang kekalahan dari musuh dan kebulatan tekad (Peterson, 2000; Dreyfuss, 1984; Chijiiwa, 1987).

Tabel 1. Perbandingan ketiga lambang negara

\begin{tabular}{ll}
\hline & Indonesia \\
\hline Jenis & Javan Hawk-Eagle \\
burung & $\begin{array}{l}\text { Merupakan spesies asli dari } \\
\text { Indonesia, melambangkan } \\
\text { Ketinggian dan semangat } \\
\text { Kepala }\end{array}$ \\
& $\begin{array}{l}\text { Menghadap kanan yang } \\
\text { mengartikan arah yang baik. }\end{array}$
\end{tabular}

Kaki Kaki burung pada lambang negara Kedua kaki pada lambang negara Indonesia mencengkeram pita yang bertuliskan "Bhinneka Tunggal Ika”, merupakan semboyan negara yang mengartikan bahwa bangsa Indonesia terdiri dari berbagai macam suku tetapi tetap bersatu.

Perisai Perisai yang terdapat pada lambang negara Indonesia adalah berbentuk persegi meruncing ke bawah. Perisai merupakan senja yang digunakan untuk mencapai dibutuhkan. Pada perisai digambarkan ideologi dari tiap propinsi di Romania dari Pancasila yang dibagi menjadi 5 bagian

Bentuk Bentuk bintang pada lambang Bintang negara Indonesia dapat ditemukan pada bagian dalam perisai yang melambang sila pertama dari Pancasila. Sila pertama pada Pancasila yang dilambangkan dengan gambar bintang memiliki bunyi Ketuhanan Yang Maha Esa. Bintang adalah penerangan pada malam hari, sama halnya dengan Tuhan yang selalu membantu umatnya saat menghadapi kesulitan.

Bentuk Bentuk bintang pada lambang Binatan negara Indonesia dapat g ditemukan pada simbol dari sila keempat yang terdapat pada bagian dari perisai. Sila keempat pada Pancasila yang dilambangkan dengan gambar kepala banteng yang berbunyi Kerakyatan yang dipimpin oleh hikmat kebijaksanaan dalam permusyawarahan/ perwakilan. Banteng merupakan binatang yang tangkas dan kuat serta tidak akan menyerang jika diganggu sama halnya dengan negara Indonesia yang gagah berani karena kebenaran dan rela berkorban. Singa yang digambarkan memegang pedang memberikan arti tentang kekuatan yang besar. Singa melambangkan keberanian dan kekuatan ditambah dengan gambar pedang yang memberikan kekuatan lebih lagi. Elang merupakan lambang dari kekuatan dan tekad yang tinggi. Lumba-lumba merupakan lambang dari keselamatan yang ada pada

Romania
Golden Aquila
Melambangkan keberanian, tekad
dan kemegahan.

Menghadap kanan dengan paruh menggigit salib yang mengartikan arah baik dalam pemerintahan dan pemerintahan sisi baik dalam segala ucapan dan perbuatan Kedua kaki pada lambang negara
Romania memegang pedang pada sebelah kanan yang mengartikan sebagai senjata dengan kekuatan untuk bertarung maupun pada sebelah kanan melambangkan yang bergabung membentuk negara kedaulatan dan kekuasaan. Uni Emirat Arab

Perisai berbentuk persegi meruncing Perisai berbentuk lingkar ke bawah. Perisai berfungsi untuk melambangkan sebagai menjadi senjata dalam melindungi negara dari dampak buruk yang akan masuk. perlindungan diri tanpa ada hentinya.

Terbagi menjadi 4 warna berbeda yang merupakan warna dari bagian yang merupakan perwakilan bendera nasional Uni Emirat Arab. Pada sekitar perisai terdapat 7 gambaran bintang yang melambangkan penerangan dan 7 emirat yang membentuk Uni Emirat Arab

Bentuk bintang pada lambang negara Romania dapat ditemukan pada bagian dari perisai yang terletak dibagian atas kepala auroch. Bintang pada lambang negara Romania memberikan pengertian tentang kekuatan untuk menjadi lebih baik dan sebagai penerangan dalam kegelapan

Bentuk bintang pada lambang negara Uni Emirat Arab dapat ditemukan di sekitar bentuk perisai lingkaran. Bentuk bintang melingkari bentuk perisai dengan jumlah bintang 7.7 merupakan angka kesempurnaan. Dalam negara Uni Emirat Arab, 7 melambangkan jumlah negara atau emirat yang bergabung menjadi satu negara Uni Emirat Arab. Selain itu, bintang di sini juga dapat diartikan sebagai penerangan atau nabi.

Pada lambang negara Romania Pada lambang negara Uni Emirat bentukan bintang dapat ditemukan Arab tidak ditemukan adanya pada setiap bagian dari dalam penggunaan bentuk binatang lain perisai, yaitu auroch, singa, elang selain burung elang yang digunakan dan lumba-lumba. Auroch sebagai lambang negara. Laut Hitam yang merupakan perbatasan dari negara Romania. 
Tabel 1. (lanjutan)

\begin{tabular}{|c|c|c|c|}
\hline & Indonesia & Romania & Uni Emirat Arab \\
\hline$\overline{\text { Warna }}$ & Warna kuning keemasan yang & Warna kuning keemasan pada & Warna kuning keemasan pada \\
\hline Kuning & digunakan pada lambang & lambang negara Romania & lambang negara Uni Emirat Arab \\
\hline \multirow[t]{5}{*}{ Keemasan } & negara Indonesia & \multicolumn{2}{|c|}{ melambangkan tentang kemegahan. melambangkan tentang kekuatan. } \\
\hline & melambangkan tentang & \multirow{4}{*}{$\begin{array}{l}\text { Warna kuning keemasan } \\
\text { merupakan warna dominan dari } \\
\text { lambang negara Romania. }\end{array}$} & Warna kuning keemasan \\
\hline & kebijaksanaan, keagungan dan & & merupakan warna dominan yang \\
\hline & kehormatan. & & digunakan dalam lambang negara \\
\hline & $\begin{array}{l}\text { Warna kuning keemasan } \\
\text { adalah warna dominan yang } \\
\text { digunakan dalam lambang } \\
\text { negara Indonesia }\end{array}$ & & Uni Emirat Arab \\
\hline \multirow{7}{*}{$\begin{array}{l}\text { Warna } \\
\text { Merah }\end{array}$} & Warna merah pada lambang & \multirow{7}{*}{$\begin{array}{l}\text { Warna merah dapat ditemukan } \\
\text { pada warna latar dari ikon propinsi } \\
\text { Moldavia dan Banat serta warna } \\
\text { kaki dari burung elang. Warna } \\
\text { merah mengartikan tentang } \\
\text { keberanian dan kekuatan dari } \\
\text { bangsa Romania dalam } \\
\text { mempertahankan negaranya. }\end{array}$} & Warna merah pada lambang negara \\
\hline & negara Indonesia dapat & & Uni Emirat Arab dapat ditemukan \\
\hline & ditemukan pada warna latar & & pada bagian dalam perisai. Warna \\
\hline & $\begin{array}{l}\text { darl simbol yang terdapat pada } \\
\text { perisai. Warna merah pada }\end{array}$ & & $\begin{array}{l}\text { merah pada perısal merupakan } \\
\text { warna merah yang sama terdapat }\end{array}$ \\
\hline & lambang negara Indonesia & & pada bendera nasional Uni Emirat \\
\hline & & & \\
\hline & $\begin{array}{l}\text { bendera nasional Indonesia, } \\
\text { yaitu untuk mengartikan } \\
\text { tentang keberanian. }\end{array}$ & & $\begin{array}{l}\text { keberanian negara dalam melawan } \\
\text { penjajahan, semangat dan kekuatan } \\
\text { serta kesatuan. }\end{array}$ \\
\hline \multirow{8}{*}{$\begin{array}{l}\text { Warna } \\
\text { Putih }\end{array}$} & Warna putih dapat ditemukan & \multirow{8}{*}{$\begin{array}{l}\text { Warna putih ditemukan pada warna } \\
\text { dari pedang, tongkat, conquefoil } \\
\text { serta bulan sabit. Warna putih } \\
\text { memberikan pengertian tentang } \\
\text { kebijaksanaan dan kejujuran. }\end{array}$} & Warna putih pada lambang negara \\
\hline & pada warna latar dari simbol & & Uni Emirat Arab merupakan \\
\hline & yang terdapat pada perisai serta & & lambang dari kedamaian dan \\
\hline & pada warna pita yang & & kejujuran. \\
\hline & dicengkeram oleh burung. & & \\
\hline & $\begin{array}{l}\text { Warna putih mengartikan } \\
\text { tentang kesucian, kejujuran, }\end{array}$ & & \\
\hline & kesempurnaan dan & & \\
\hline & kebijaksanaan. & & \\
\hline \multirow{7}{*}{$\begin{array}{l}\text { Warna } \\
\text { Hijau }\end{array}$} & Warna hijau dapat ditemukan & \multirow{7}{*}{$\begin{array}{l}\text { Lambang negara Romania tidak } \\
\text { menggunakan warna hijau }\end{array}$} & \multirow{7}{*}{$\begin{array}{l}\text { Warna hijau pada bendera yang } \\
\text { terdapat pada perisai merupakan } \\
\text { lambang dari tanah atau lahan dari } \\
\text { negara Uni Emirat Arab yang subur, } \\
\text { harapan, kebahagian serta } \\
\text { kegembiraan. }\end{array}$} \\
\hline & pada warna dari pohon beringin & & \\
\hline & yang menjadi ikon dari sila & & \\
\hline & ketiga dan kapas pada sila & & \\
\hline & kelima. Warna hijau & & \\
\hline & memberikan arti tentang & & \\
\hline & $\begin{array}{l}\text { kesuburan, kebahagian, } \\
\text { kesegaran dan keberunutungan. }\end{array}$ & & \\
\hline & Warna hitam dapat ditemukan & \multirow{5}{*}{$\begin{array}{l}\text { Lambang negara Romania tidak } \\
\text { menggunakan warna hitam }\end{array}$} & \multirow{5}{*}{$\begin{array}{l}\text { Warna hitam pada bendera yang } \\
\text { terdapat pada perisai merupakan } \\
\text { lambang dari kemenangan melawan } \\
\text { musuh dan kebulatan tekad. }\end{array}$} \\
\hline \multirow[t]{4}{*}{ Hitam } & pada warna latar dari sila & & \\
\hline & pertama dan warna dari kepala & & \\
\hline & banteng. Warna hitam & & \\
\hline & $\begin{array}{l}\text { mengartikan tentang kekuatan } \\
\text { dan kemakmuran }\end{array}$ & & \\
\hline
\end{tabular}

Pada lambang negara Indonesia, Garuda Pancasila merupakan sebuah ikon, indeks serta simbol dari negara Indonesia. Sebagai ikon Garuda Pancasila mewakili negara Indonesia. Sebagai indeks Garuda Pancasila memberikan pandangan tentang ideologi dari pandangan kehidupan bangsa Indonesia. Sedangkan sebagai simbol, Garuda Pancasila telah disahkan secara hukum oleh bangsa Indonesia. Peraturan ini dapat dilihat pada Undang-Undang Dasar Negara Republik Indonesia Bab XV Pasal 36a.

Pada lambang negara Indonesia, burung garuda merupakan sebuah ikon dari burung Javan HawkEagle. Burung elang memberikan indeks tentang ketinggian dan semangat yang membara. Peng- gunaan warna kuning keemasan sebagai indeks dari sifat bijaksana dan kehormatan. Kepala burung pada lambang negara digambarkan menengok ke kanan yang merupakan indeks dari arah kebaikan. Pada tradisi perwayangan serta secara politik sebelah kanan merupakan tempat dari tokoh protagonis. Pada bagian kaki burung dapat ditemukan pita bertuliskan semboyan hidup bangsa Indonesia yang berbunyi "Bhinneka tunggal Ika”. Semboyan ini merupakan indeks dari bangsa Indonesia yang terdiri dari banyak suku tetapi tetap bersatu dan membentuk negara Republik Indonesia. Perisai yang terdapat pada dada burung merupakan representasi ikon-ikon tiap sila dalam Pancasila. Perisai sebagai ikon memiliki kemiripan pada bentuk perisai pada 
umumnya dan sebagai indeks perisai berperan untuk melindungi negara. Pada bagian perisai terbagi menjadi lima ikon yang mewakili tiap sila dari Pancasila. Pada sila pertama yang berbunyi Ketuhanan Yang Maha Esa diwakili dengan gambar dari bintang yang memiliki lima sudut. Bintang merupakan indeks dari ketuhanan dan penerangan dalam kegelapan. Sila kedua yang berbunyi kemanusian yang adil dan beradab digambarkan dengan ikon berbentuk rantai. Rantai merupakan indeks dari hubungan atau pertalian yang abadi. Sila ketiga yaitu persatuan Indonesia dilambangkan dengan ikon dari pohon beringin. Pohon beringin merupakan lambang dari kesuburan tanah. Sila keempat yang berbunyi kerakyatan yang dipimpin oleh hikmat kebijaksanaan diwakili dengan gambar kepala banteng. Banteng merupakan indeks tentang kekuatan. Dan yang terakhir adalah sila kelima yang diwakili oleh gambar padi dan kapas untuk menggambarkan keadilan sosial bagi seluruh rakyat Indonesia. Padi dan kapas merupakan indeks dari sandang dan pangan dari bangsa Indonesia.

Lambang negara Romania merupakan sebuah ikon, indeks serta simbol. Sebagai ikon, lambang negara Romania berfungsi untuk mewakili negara Romania. Sebagai indeks, lambang negara Romania menampilkan tentang daerah yang menjadi bagian dari wilayah Romania. Sedangkan sebagai simbol lambang negara Romania dapat dilihat pada peraturan no. 102 pada tahun 1992.

Burung yang digunakan dalam lambang negara Romania adalah burung yang disebut dengan Golden Aquila sehingga burung ini merupakan sebuah ikon. Secara indeks, Golden Aquila yang melambangkan keberanian, tekad dan kemegahan. Kepala dari burung yang menghadap ke kanan merupakan indeks arah baik. Salib yang berada di paruh burung merupakan indeks dari ucapan dan perbuatan berdasarkan pada agama. Pada bagian kaki burung terdapat gambar pedang dan tongkat. Pedang pada sebelah kanan yang merupakan indeks dari kekuatan untuk bertarung maupun mempertahankan diri. Tongkat pada sebelah kanan melambangkan kedaulatan dan kekuasaan. Di dada burung terdapat sebuah perisai yang berfungsi untuk menjadi senjata dalam melindungi negara. Pada perisai terbagi menjadi 5 bagian yang merupakan perwakilan dari tiap propinsi di Romania. Propinsi Wallachia memiliki ikon burung elang berparuh menggigit salib serta bentuk bulan dan matahari di kedua sisi burung. Matahari merupkan indeks dari kebebasan dan masa depan, sedangkan bulan sabit adalah kekuatan yang mengagungkan. Propinsi Moldavia digambarkan dengan ikon auroch, bintang, cinquefoil serta bulan sabit. Auroch merupakan indeks dari kerendahan hati, dan rela berkorban. Bintang berfungsi sebagai penerangan. Cinquefoil merupakan sebuah tujuan yang ingin dicapai oleh Moldavia. Propinsi Banat digambarkan dengan ikon singa yang memegang pedang diatas sebuah jembatan yang dibawahnya terdapat gelombang air. Singa melambangkan keberanian dan kekuatan yang besar ditambah pula dengan gambar pedang yang memberikan kekuatan. Jembatan menggambarkan penghubungan atau perubahan yang diinginkan. Gelombang air memberikan pengertian tentang penyucian. Propinsi Tranylvania digambarkan dengan burung yang di kedua sisinya terdapat matahari dan bulan sabit serta 7 buah benteng di bawahnya. Benteng melambangkan kekuatan untuk mempertahankan negara. Perbatasan Laut Hitam digambarkan dengan gambar dua buah lumba-lumba dengan posisi kepala di bawah. Lumba-lumba ini melambangkan keamanan dan posisi kepala di bawah untuk menggambarkan lumba-lumba saat menyelam ke dalam air sebagai penyelamat.

Pada lambang negara Uni Emirat Arab terdapat ikon indeks dan simbol. Sebagai ikon, lambang negara Uni Emirat Arab mewakili negara Uni Emirat Arab. Sebagai indeks, lambang negara Uni Emirat Arab memberikan pengertian tentang perkumpulan dari negara-negara emirat yang bergabung membentuk Uni Emirat Arab. Dari segi simbol, peraturan yang membentuk lambang negara dari Uni Emirat Arab dapat dilihat dari surat keputusan federal nomor 3 untuk tahun 2010.

Pada lambang negara Uni Emirat Arab burung yang digunakan adalah burung Golden Falcon yang merupakan ikon yang mewakili negara Uni Emirat Arab. Golden Falcon merupakan indeks dari kekuatan yang besar. Pada lambang negara Uni Emirat Arab dapat dilihat bahwa kepala dari burung menghadap ke kanan. Kanan dalam pemerintahan merupakan indeks dari sisi yang baik. Pada bagian bawah lambang negara, dapat

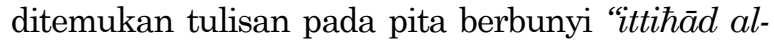
jumhüriyyāt al-Arabiyya", yang berartikan federasi republik Arab. Federasi republik Arab merupakan sebuah perkumpulan dari 7 emirat yang bergabung membentuk negara Uni Emirat Arab. Pada bagian dada burung dapat ditemukan sebauh perisai berbentuk lingkar yang merupakan indeks dari perlindungan diri tanpa ada hentinya. Pada perisai terbagi menjadi 4 warna berbeda yang merupakan warna dari bendera nasional Uni Emirat Arab. Pada sekitar perisai terdapat tujuh gambaran bintang yang merupakan indeks dari penerangan dan juga sebagai ikon dari tujuh 
emirat yang bergabung membentuk Uni Emirat Arab. Warna merah pada bendera yang terdapat pada perisai merupakan indeks dari keberanian negara dalam melawan penjajahan, semangat dan kekuatan serta kesatuan. Warna hijau pada bendera yang terdapat pada perisai merupakan indeks dari tanah atau lahan dari negara Uni Emirat Arab yang subur, harapan, kebahagian serta kegembiraan. Warna putih pada bendera yang terdapat pada perisai merupakan indeks dari kedamaian dan kejujuran. Warna hitam pada bendera yang terdapat pada perisai merupakan indeks dari kemenangan melawan musuh dan kelingkaran tekat.

Dari ketiga negara dapat diketahui bahwa terdapat beberapa persamaan walaupun tidak dapat diketahui secara langsung. Seperti contohnya makna dari Ketuhanan atau keagamaan. Pada negara Indonesia makna Ketuhanan dapat dilihat atau ditemukan pada simbol di perisai yang menggambarkan bintang. Pada negara Romania, Ketuhanan dapat ditemukan pada gambar salib yang diletakkan pada paruh burung. Sedangkan pada negara Uni Emirat Arab dapat ditemukan pada tujuh bintang yang berada di sekitar perisai yang melambangkan emirat (nabi). Makna keberanian selain dari burung ketiga negara menggambarkan secara berbeda yaitu dari negara Indonesia digambarkan dengan kepala banteng, pada negara Romania dari gambar singa sedangkan pada negara Uni Emirat Arab lebih ditampilkan secara sederhana yaitu hanya dengan menggunakan warna merah.
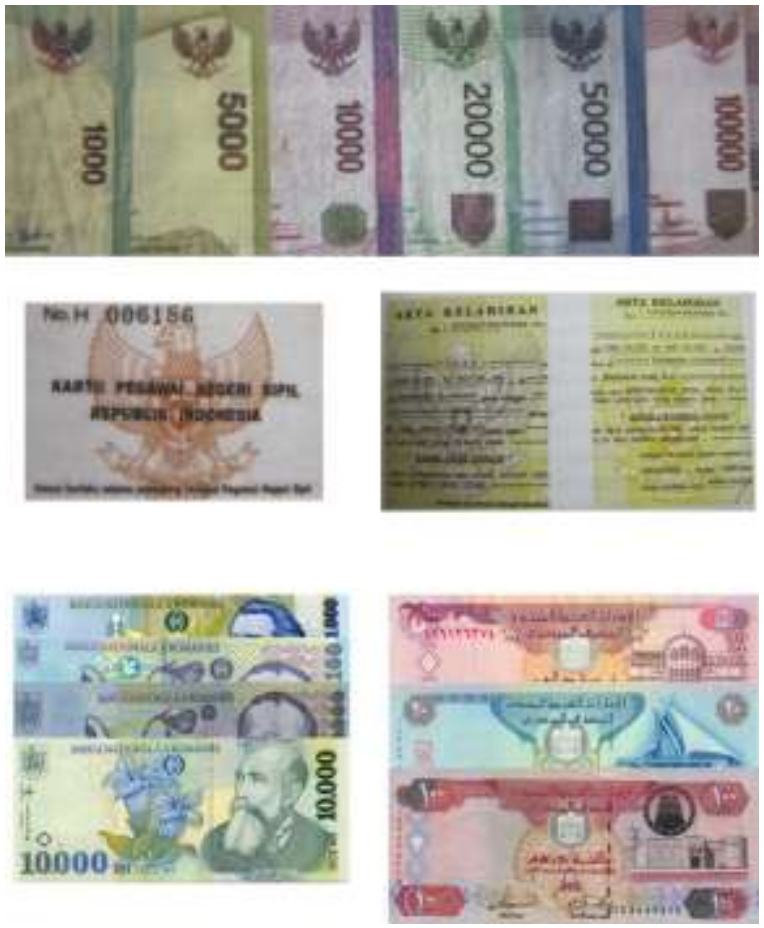

Gambar 19. Pengaplikasian lambang negara
Ketiga lambang negara dari Indonesia, Romania, maupun Uni Emirat Arab merupakan sebuah lambang yang telah menjadi simbol nasional dari tiap negara. Pengunaan lambang negara tidak boleh digunakan secara sembarangan. Oleh karena itu terdapat peraturan yang mengikat tentang penggunaan dari lambang negara tersebut. Lambang negara banyak diterapkan pada bangunan negara, dokumen negara, mata uang, dan lain sebagainya. Sehingga masyarakat secara luas mengerti tentang penggunaan lambang negara yang tidak boleh digunakan secara sembarangan.

Pada ketiga lambang negara dapat pula ditemukan beberapa perbedaan, seperti makna kesuburan tanah. Negara Indonesia dan Uni Emirat menggunakan simbol yang menyatakan kesuburan tanah, seperti penggunaan pohon beringin dan pada negara Uni Emirat Arab menggunakan warna hijau. Tetapi pada negara Romania tidak terdapat simbolisasi yang mengandung makna ini. Selain itu pada negara Indonesia terdapat penggunaan simbol padi dan kapas yang mengartikan tentang sandang dan pangan yang tidak diperlihatkan oleh kedua lambang negara lainnya. Berbeda dengan Romania yang merupakan negara kaya, pada saat pembuatan lambang negara, Indonesia baru mendapatkan kemerdekaan dari penjajahan selama bertahun-tahun sehingga menurut Indonesia pangan adalah salah satu hal yang penting untuk dapat menciptakan negara Indonesia yang bersatu.

Secara keseluruhan dapat dilhat bahwa lambang negara dari Indonesia lebih bermakna dibandingkan lambang negara dari Romania dan Uni Emirat Arab. Hal ini dapat dilihat dari lambang negara Indonesia yang memberikan atau memasukkan pandangan hidup mereka ke dalam lambang negaranya. Ditambah lagi dengan semboyan yang ada pada kaki burung. Berbeda dengan negara Uni Emirat Arab yang hanya menuliskan nama nasional dari negara mereka. Lambang negara dari Uni Emirat Arab digambarkan secara sederhana dengan penggunaan sedikit ikon tetapi makna-makna yang penting tetap terdapat didalamnya. Sedangkan lambang negara Romania lebih kompleks dengan penggambaran berbagai ikon dari daerah yang menjadi kawasan Romania.

\section{Kesimpulan}

Dari penelitian yang telah dilakukan didapatkan kesimpulan bahwa ketiga lambang negara memiliki beberapa perbedaan dan kesamaan. Secara keseluruhan bentuk dari lambang negara meng- 
alami kemiripan, tetapi makna yang terkandung dalam lambang negara tidak sepunuhnya sama. Ketiga negara sama-sama memiliki persepsi bahwa burung elang merupakan indeks dari keberanian. Namun pengambaran dari persepi dari tiap negara berbeda sehingga burung elang yang digunakan bukanlah burung elang yang berasal dari spesies yang sama. Berbeda dengan posisi kepala, ketiga negara mendapat pengaruh yang sama, yaitu parlemen revolusioner Perancis serta tradisi atau mitos yang terdapat di negara mereka. Sehingga ketiga burung pada lambang negara menengok pada sebelah kanan. Ketiga negara memiliki pandangan berbeda tentang apa yang harus ditampilkan pada sebuah lambang negara. Negara Indonesia menampilkan ideologi dan pandangan hidup dari bangsanya dalam lambang negara memalui penggambaran perisai Pancasila dan semboyan pada pita yang dicengkeram pada kaki burung. Negara Romania menampilkan daerah yang menjadi bagian dari negara Romania serta penggunaan pedang dan tongkat pada kaki burung yang digunakan untuk menampilkan kekuasan dan kekuatan. Berbeda dengan negara Uni Emirat Arab yang lebih secara jelas menampilkan bendera negaranya sebagai bagian dari lambang negara serta tulisan bahasa Arab yang terletak di pita pada bagian kaki burung yang menyatakan tentang nama nasional dari Uni Emirat Arab. Lambang negara merupakan sebuah bentuk perwakilan dari sebuah negara yang digali oleh berbagai aspek, seperti geografis, agama, budaya dan lain sebagainya. Oleh karena itu, walaupun lambang negara memiliki penggambaran yang dapat dikatakan mirip tetapi makna yang terdapat di dalam lambang negara antar negara tidak selalu sama.

\section{Daftar Pustaka}

Achen, Sven Tito. (1978). Symbols Around Us. New York: Van Nostrand Reinhold.

Budiman, Kris. (2011). Semiotika Visual. Yogyakarta: Jalasutra.

Biedermann, Hans. (1992). Dictionary of Symbolism. New York: Fact in File.

Chandler, Daniel. (2007). Semiotics: The Basics .2 ${ }^{\text {nd }}$ ed. New York: Routledge.

Cirlot, J.E. (1971). Dictionary of Symbols. London: Routledge \& Keagen Paul Ltd.
Cobley, Paul. (1997). Semiotics a Graphic Guide. Malta: Gutenburg Press.

Dreyfuss, Henry. (1984). Symbol sourcebook: An Authoritative Guide to International Graphic Symbols. New York: John Wiley \& Sons, Inc.

Encyclopaedia Britannica, Inc. (1983). Encyclopaedia Britannica. Chichago: William Benton Publisher.

Encyclopaedia Britannica, Inc. (2010). Encyclopaedia Britannica Year Book 2010. Chichago: William Benton Publisher.

Ensiklopedia Nasional Indonesia. (2004). Jilid 4, PT Delta Pamungkas: Bekasi. 2004.

Fontein, Jan. (1990). The Sculpture of Indonesia. Washington: National Gallery of Art.

Frutiger, Andrian. (1989). Sign and Symbols Their Design and Meaning. New York: Van Nostrand Reinhold.

Hidayat, Nanang R. (2009). Mencari Telur Garuda. Jakarta: Nalar.

Hoopes, James (ed.). (1991). Peirce on Signs: Writing on Semiotic by Charles Sanders Peirce. The University of North Carolina Press.

MacKinnon, John. (1990). Field Guide to The Birds of Java and Bali. Yogyakarta: Gadjah Mada University Press.

McNab, Chris. (2010). Knives and Sword a Visual History. New York: DK Publishing.

Mangoenrahardjo, Soetomo. (1976). Ikhtisar Pokok dan Tokoh Mitologi Yunani-Romawi. Bandung: Tarate.

Moleong, Lexy J. (2007). Metodologi Penelitian Kualitatif. Bandung: Pt. Remaja Rosdakarya.

Ensiklopedi Indonesia Seri Fauna. 1988. Jakarta: PT. Ichtiar Baru - van Hoeve.

Regan, Paula. (2006). Weapon: a Visual History of Arms and Armor. New York: DK Publishing.

Rose, Gillian. (2001). Visual metodologies. London: Sage Publications Ltd.

Sahabat Museum Konfernsi Asia-Afrika. (2011). Perjalanan 60 Tahun Elang Garuda Pancasila, Catatan Seminar \& Pameran 2011. Bandung: Museum Konferensi Asia-Afrika.

Soekatno. (1992). Mengenal Wayang Kulit Purwo. Semarang: Aneka Ilmu.

Sobur, Alex. (2009). Semiotika Komunikasi. Bandung: PT. Remaja Rosdakarya.

Souli, Sofia. (1995). Greek Mytology. Attiki: Michael Toubis Publication. 